\title{
SANÇÕES ADMINISTRATIVAS AMBIENTAIS
}

\author{
ÁlVARo LAZZARINI* \\ 1. Considerações Gerais. 2. Direito Ambiental e Poder de Polícia. 3. \\ Polícia Administrativa Ambiental e Polícia Judiciária Ambiental. 4. San- \\ ções Administrativas Ambientais. 5. Conclusão.
}

\section{Considerações Gerais}

Há aspectos de Direito Administrativo que causam polêmicas sérias quanto à competência para o exercício do Poder de Polícia Ambiental, nos quatro modos de atuação a que se refere Diogo de Figueiredo Moreira Neto $^{1}$, ou seja, a quem cabe a ordem de polícia, a quem cabe o consentimento de polícia, a quem cabe a fiscalização de polícia e a aplicação da sanção de polícia, aliás, conforme tive oportunidade de examinar em monografias que cuidam de A proteção do Meio Ambiente pela Polícia Militar $^{2}$, que diz respeito ao Direito Ecológico, e do Direito Administrativo e Prevenção de Incêndio ${ }^{3}$, bem como em $O$ Corpo de Bombeiros e o Poder de Polícia ${ }^{4}$, esses dois últimos direcionados ao Direito Urbanístico, embora o incêndio em uma floresta ou, então, em uma mata seja uma catástrofe ecológica e sua prevenção seja Poder de Polícia Ambiental.

1 FIGUEIREDO MOREIRA NETO, Diogo de. Obra de ed. cits., p. 340.

2 LAZZARINI, Alvaro. Proteçāo do Meio Ambiente pela Polícia Militar. "Revista de Informação Legislativa", Senado Federal, Subsecretaria de Ediçōes Técnicas, Brasilia, a. 29, n. 116, out/dez. 1992, p. 153-162.

3 LAZZARINI, Alvaro. Direito Administrativo e Prevenção de Incêndio, "Revista de Direito Administrativo", Editora Renovar, Rio de Janeiro, out/dez. 1991, v. 186, p. 114-132.

4 LAZZARINI, Alvaro et alii. O Corpo de Bombeiros e o Poder de Polícia, Imprensa Oficial do Estado, São Paulo, 1992, p. 13-23.

* Desembargador do Tribunal de Justiça do Estado de São Paulo, Professor de Direito Administrativo da Academia de Polícia Militar do Barto Branco e da Escola Paulista da Magistratura e Sócio Colaborador do Instituto dos Advogados de São Paulo. 
Ao certo, o implemento de medidas legais pelo Poder Público para a proteção ambiental do homem só se torna possivel, administrativa, civil e penalmente, pelo regular exercício do Poder de Polícia, quer na preservação, quer na conservação do meio ambiente, aquela não admitindo o seu uso, com ausência de ação antrópica, esta, a conservação, admitindo o uso, com o manejo auto-sustentado ${ }^{5}$.

\section{Direito ambiental e poder de polícia}

A nossa Carta de 1988, no art. 23, III, VI e VII, estabelece ser da competência comum da Uniāo, dos Estados, do Distrito Federal e dos Municípios "proteger os documentos, as obras e outros bens de valor histórico, artístico e cultural, os monumentos, as paisagens naturais notáveis e os sítios arqueológicos, protegendo, assim, o meio ambiente e combatendo a poluição em qualquer de suas formas preservando as florestas, a fauna e a flora". No art. 24, I, estabelece a competência da União, dos Estados e do Distrito Federal para legislar concorrentemente sobre direito urbanístico, que diz respeito à denominada massa cinza, cabendo à União a competência limitada de estabelecer normas gerais (art. $\left.24, \S 1^{Q}\right)$, o que não exclui a competência suplementar dos Estados (art. $24, \S 2^{\underline{a}}$ ), salvo se inexistir lei federal sobre normas gerais hipótese que os Estados exercerão a competência plena, para atender as suas peculiaridades (art. $24, \S 3^{0}$ ), certo, contudo, que a superveniência de lei federal sobre normas gerais suspende a eficácia da lei estadual no que lhe for contrário (art. 24, $\S 4^{2}$ ).

A Constituição de 1988 dedica, outrossim, todo um capítulo ao meio ambiente (Capítulo VI do Título VIII, que trata da Ordem Social), consubstanciando, no seu art. 225 , com 6 (seis) parágrafos e 7 (sete) incisos no seu $\S 1^{9}$. No cuidar sobre os princípios gerais da atividade econômica, no Capítulo I do Título VII, que trata $D a$ Ordem Econômica e Financeira, o art. 170, estabelece que a ordem econômica, fundada na valorização do Trabalho humano e na livre iniciativa, tendo por fim assegurar a todos a existência digna, conforme os ditames da justiça social, observará, entre outros, o princípio de defesa do meio ambiente (art. 170, VI).

No Estado de São Paulo, a Constituição Estadual de 1989, cuida "Do Meio Ambiente, dos Recursos Naturais e do Saneamento", no Capítulo IV do Título VI, que é o "Da Ordem Econômica", arts. 191 a 216.

O Município rege-se por lei orgânica, que deve atender os princípios estabelecidos na Constituição do respectivo Estado, por expressa exigência do art. 29 caput, da Constituição de 1988, e art. 144 da Constituição do Estado, competindo-lhe, nos termos do art. 30 daquela Carta Federal, legislar sobre assuntos de interesse local (art. 30, I), suplementar a legislação federal e a estadual no que couber (art. 30, II), promover, no que couber, adequado ordenamento territorial, mediante planejamento e controle do uso, do parcelamento e da ocupação do solo urbano (art. 30, VIII).

5 MELE, João Leonardo. Quadro Sinóptico do Direito Ambiental no Brasil, 1994, São Paulo, trabalho inédito. 
Dessa normatização constitucional, como assevera o ambientalista Vladimir Passos de Freitas ${ }^{6}$, surge, para as entidades federadas, a atribuição do poder de legislar e, como consequiência direta, o de fiscalizar, sendo que fiscalização, como entendo, é um dos modos de atuação do poder de polícia, com a dupla utilidade de realizar a prevenção das infrações pela observação do comportamento dos administrados, relativamente às ordens e aos consentimentos de polícia; em segundo lugar, prepara a repressão das infrações pela constatação formal dos atos infringentes, tudo conforme lição de Diogo de Figueiredo Moreira Neto a que voltarei logo mais.

Pode, pois, a denominada Polícia Ambiental ser executada pela União, Estados, Distrito Federal e Municípios, certo que, como salienta Vladimir Passos de Freitas, "este poder que é, normalmente, exercido para limitar os direito individuais, pode ser dirigido, também, contra as mesmas pessoas jurídicas de Direito Público. Entre elas não há hierarquia no nosso sistema federativo. Assim, desde que uma delas esteja atuando nos limites de sua competência, firmada na Constituição Federal, as outras deverão curvar-se e obedecer" ${ }^{7}$, inclusive, na regularização fundiária nas áreas de interesse ambiental.

Lei, como exemplo, do município paulista de Santos, que a pretexto de proibir a captura do "callichirus SP", o conhecido "corrupto", na orla marítima do município, determinou competir à Guarda Municipal a fiscalização do seu cumprimento ${ }^{8}$, é lei de duvidosa constitucionalidade no que concerne à competência municipal para subsistir medida da Polícia Florestal do Estado de São Paulo quanto a Guarda Municipal, atribuindo a esta atividade que lhe é vedada, pois, a sua competência está prevista no art. $144, \S 8^{\circ}$, da Constituição de 1988 , sendo pacífica a doutrina e jurisprudência no sentido de que não cabe às guardas municipais os serviços de polícia ostensiva, de preservação da ordem pública, de polícia judiciária e de apuração de infraçōes penais ${ }^{9}$, por ser guarda patrimonial ${ }^{10}$.

O exercício do poder de polícia ambiental, como adverte Paulo Affonso Leme Machado", "supõe a existência e a atuação de órgão público ambiental", com

6 PASSOS DE FREITAS, Vladimir. Direito Administrativo Ambiental, 1993, Juruá Editora, Curitiba, p. 71 .

7 PASSOS DE FREITAS, Vladimir. Obra e ed. cit. p. 73

8 Lei $n^{2} 1.293$, de 17 de dezembro de 1993, do Município de Santos, São Paulo, art. $1^{\circledR}$, que alterou o parágrafo único do art. $2^{2}$ da Lei $n^{2} 850$, de 19 de março de 1992, dando-lhe nova redação.

9 ACÓRDÃO unânime da Quinta Câmara Criminal do Tribunal de Justiça do Estado de São Paulo, em 27 de maio de 1993, na apelaçāo criminal $n^{2}$ 140.786-3, de Cotia, relator Desembargador Dante Busana, in "Jurisprudência do Tribunal de Justiça", LEX editora, São Paulo, v. 146, p. 304-308; idem acórdão unânime da Quinta Câmara Criminal do Tribunal de Justiça do Estado de São Paulo, em 03 de março de 1994, na apelaçāo criminal $n^{2}$ 124.767-3/5, de Americana, relator Desembargador Cunha Bueno, ainda não constante de repertórios de jurisprudência; idem ACÓRDĀO unânime da Segunda Câmara Criminal do Tribunal de Justiça do Estado de São Paulo, na apelação criminal n² 96.007-3/7, de Araras, relator Desembargador Weiss de Andrade, apud CRETELLA JÚNIOR, José. Comentários à Constituição Brasileira de 1988, 1² ed., 1992, Forense Universitária, Rio de Janeiro, p. 3.426.

10 idem, ibidem.

1I LEME MACHADO, Paulo Affonso. Estudos de Direito Ambiental, 1994, Malheiros Editores, São Paulo, p. 79. 
competência para a prática do ato que o concretiza, isso acrescento, mesmo porque é em esse sentido que entendo a idéia sintetizada no "princípio 10 da Declaração do Rio de Janeiro (UNCED/92), que com a adesão unânime dos membros da ONU, afirmou: " $\mathrm{O}$ melhor modo de tratar as questões ambientais é assegurar a participação, em nível relevante, de todos os cidadãos interessados. No plano nacional, cada indivíduo deve ter adequado acesso às informações relativas ao meio ambiente, que estejam em poder das autoridades públicas, compreendidas as informações concernentes às substâncias e atividades perigosas existentes em suas comunidades, e ter possibilidade de participar no processo de tomada de decisões. Os Estados devem facilitar e encorajar a conscientização e participação do público tornando as informações facilmente disponíveis. Deve ser assegurado acesso efetivo aos processos judiciais e administrativos, inclusive no concernente às sanções e reparações".

A participação de todos os cidadãos interessados, em nível relevante, e o encorajamento pelo Brasil para essa participação, no entanto, não está a dizer que todas pessoas físicas ou jurídicas, de direito público ou de direito privado, podem exercer atividade de polícia ambiental, como examinarei na Teoria Geral do Poder de Policia, que logo abordarei.

Lembro, antes, que a cada restrição de direito individual - expressa ou implícita na norma legal - corresponde equivalente Poder de Polícia Administrativa à Administração Pública, para torná-la efetiva ou fazê-la obedecida ${ }^{12}$.

Só órgão público competente para o ato pode exercer o Poder de Polícia, à vista não só das normas constitucionais, como infraconstitucionais e, também infralegais, enfim de um extenso emaranhado de leis, decretos e resoluçōes, o que Édis Milaré denominou de "Textos básicos sobre o meio ambiente no Brasil, de acordo com a nova ordem constitucional e com as inovaçöes introduzidas pelo 'Programa Nossa Natureza' e 'Plano Brasil Novo'", textos estes que renderam 636 (seiscentos e trinta e seis) páginas do seu precioso livro Legislação Ambiental no Brasil, editado por Edições APMB, em São Paulo, no ano de 1991. Tal emaranhado está a indicar a urgente necessidade de uma Codificação, senão total pelo menos parcial do denominado Direito Ambiental, ou, ainda, a sua Consolidação, tudo para dar segurança jurídica, não só para os operadores do Direito, sejam juristas ou policiais, como, e principalmente, para o administrado, ou seja, o povo que tem direito ao meio ambiente ecologicamente equilibrado.

Ao certo, nesta oportunidade, não irei interpretar e, tampouco, decifrar esse emaranhado que se denomina legislação ambiental no Brasil de hoje. Penso, no entanto, que a Teoria Geral do Poder de Polícia auxiliará a compreender a ação do Estado frente à problemática do meio ambiente, quer por parte dos órgãos públicos que constituem o Sistema Nacional do Meio Ambiente (SISNAMA), como por parte dos cidadãos interessados no magno problema do meio ambiente no Brasil, inclusive no que toca à efetivação da regularização fundiária.

12 LOPES MEIRELLES, Hely. Direito Administrativo Brasileiro, 18 ed., 1993, atualizada por Eurico de Andrade Azevedo, Délcio Balestero Aleixo e José Emmanuel Burle Filho, Malheiros Editores, Sảo Paulo, p. 117. 
Passo, assim, a examinar o Poder de Policia, que é o poder que, como início visto, tem como modos de atuação, entre outros, a fiscalização, como também a aplicą̧ão da sanção de polícia, este último como objeto deste estudo.

\section{Polícia administrativa ambiental e polícia judiciária ambiental}

Há, no Poder de Policia, uma dicotomia que interessa à preservação e à conservação do meio ambiente. Esse poder administrativo, com efeito, se concretiza em duas atividades, ou seja, a de polícia administrativa e a de polícia judiciária, ambas presentes na temática do Direito Ambiental. A dicotomia, no entanto, tem gerado confusão não só no espírito dos leigos, como também no do legislador, bem como disputas entre entes estatais, autárquicos fundacionais e paraestatais e, ainda, entre órgãos policiais, que não se acomodam nos limites de suas competências institucionais e, assim, nos limites do Poder de Polícia, tudo em prejuízo do administrado que, quase sempre, acaba por sucumbir aos abusos de autoridade, por excesso de poder ou desvio de poder, como é comum na Administração Pública em geral, inclusive, no manejo do Direito Ambiental.

O Poder de Polícia é um poder administrativo, porque conceitualmente, ele, que legitima o poder da polícia e a própria razão dela existir, é um conjunto de atribuições da Administração Pública, como poder público e indelegáveis aos entes particulares, embora possa estar ligados àquela, tendentes ao controle dos direitos e liberdades das pessoas, naturais ou jurídicas, a ser inspirado nos ideais do bem comum, e incidentes não só sobre elas, como também em seus bens e atividades.

Daí por que a polícia administrativa e a polícia judiciária são exteriorização de atividade tipicamente administrativa, malgrado a última polícia ser qualificada de judiciária.

A polícia administrativa propriamente dita é preventiva, regida pelas normas e princípios de Direito Administrativo, enquanto que a polícia judiciária é repressiva, exercendo atividades administrativas de auxiliar da repressão criminal. A polícia judiciária, necessário é insistir não integra o Poder Judiciário, nem como órgão administrativo. Este Poder da Soberania Nacional, num Estado Democrático de Direito, detém o monopólio da jurisdição e, bem por isso, ele é que procede a repressão criminal, sendo auxiliado pelo órgão do Poder Executivo que, administrativamente, exerce a atividade de polícia judiciária e que, assim, deve observar as normas e princípios do Direito Processual Penal.

Em tema de meio ambiente, por exemplo, os órgãos licenciadores, como possam ser o Instituto Brasileiro do Meio Ambiente e dos Recursos Naturais Renováveis e, ainda, os da Secretaria de Estado e Meio Ambiente, exercem típica atividade de polícia administrativa, dando o consentimento de polícia ou negando-o, fazendo, inclusive a fiscalização de polícia, dando suas ordens de polícia e, falhando todo o mecanismo, verificada a infração às normas da legislação ambiental de regência, quando aplicam as sanções administrativas de polícia ambiental, nos limites de suas competências. 
A repressão administrativa não se confunde com atividade de polícia judiciária, esta voltada a só apuração de ilícitos penais, inclusive, diante do Direito Ambiental e que não se confundem com polícia de segurança, setor da administrativa voltado à prevenção criminal.

O mesmo órgão, porém, pode ser eclético no exercício do Poder de Polícia, e dentro dos limites de sua competência constitucional ou infraconstitucional, porque age preventiva e repressivamente, ou seja, passa, necessária e automaticamente, da atividade policial preventiva para o exercício da atividade policial repressiva, dado que ocorreu o ilícito que não conseguiu evitar. Quando o ilícito for penal, ter-se-ia, então atividade de polícia judiciária consubstanciada na denominada repressão imediata por parte do órgão policial exercente da atividade de polícia preventiva.

Não é, aliás, o rótulo do órgão público que qualifica a atividade de polícia. $O$ que a qualifica em polícia administrativa (preventiva) e polícia judiciária (repressiva) é a sempre, a atividade de polícia em si mesmo desenvolvida.

Isto está a demonstrar que a linha de diferenciação, entre o que seja polícia administrativa (preventiva) e polícia judiciária (repressiva), é bem precisa, porque será sempre a ocorrência ou não de um ilícito penal ${ }^{13}$, posição nossa colhida por Maria Zanella Di Pietro ${ }^{14}$.

Esta distinção é importante em termos de competência administrativa para os atos previstos na legislação ambiental em vigor, lembrando-se, a propósito, algo que os órgãos envolvidos no Sistema Nacional do Meio Ambiente - SISNAMA esquecem e original conflitos de atribuições, ou seja, "A primeira condição de legalidade é a competência do agente. Não há em direito administrativo, competência geral e universal: a lei preceitua, em relação a cada função pública, a forma e o momento do exercício das atribuições do cargo. Não é competente quem quer, mas quem pode, segundo a norma de direito. A competência é, sempre, um elemento vinculado, objetivamente fixado pelo legislador" 15 .

A importância dessa distinção de polícia administrativa e de polícia judiciária acentua-se, igualmente, em termos de competência jurisdicional, pois, o controle jurisdicional do ato de polícia administrativa é da competência do órgão jurisdicional a que caiba o processo e julgamento de causas da Fazenda Pública, enquanto que ato de polícia judiciária é a do órgão que detenha a competência criminal, tudo como dispuserem as leis de organização judiciária do Estado Federado ou do Distrito Federal, quando caso.

No Estado de São Paulo, por exemplo, sem adentrar na competência da Justiça Federal, atos de polícia administrativa praticados por policiais militares na proteção do meio ambiente são julgados pelos juízes de direito que detenham a competência do cível, nas Comarcas do Interior, enquanto que na de São Paulo e na que tenha a

13 LAZZARINI, Alvaro et alii. Direito Administrativo da Ordem Pública, ed., cit., p. 37.

14 DI PIETRO, Maria Sylvia Zanella. Direito Administrativo, Editora Atlas, São Paulo, 1990, p. 90.

15 TÁCITO, Caio. O Abuso do Poder Administrativo no Brasil - Conceito e Remédios, ediçāo do Departamento Administrativo do Serviço Público e Instituto Brasileiro de Ciências Administrativas, Rio de Janeiro, 1959, p. 27. 
da Fazenda Pública a competência é das Varas da Fazenda Pública, com recurso para o Tribunal de Justiça do Estado, Primeira Seção Civil.

Aliás, em relação à Polícia Militar do Estado de São Paulo, é necessário esclarecer que ela integra o Sistema de Proteção e Desenvolvimento do Meio Ambiente, mediante as suas unidades de policiamento florestal e de mananciais. incumbidas da prevenção e repressão das infrações cometidas contra o meio ambiente, sem prejuízo dos corpos de fiscalização dos demais órgãos especializados, tudo conforme a Constituição do Estado de São Paulo, no seu art. 195, parágrafo único, que interpretei, sistematicamente, no indicado trabalho sobre A Proteção do Meio Ambiente pela Polícia Militar (infra nota 2), concluindo, então, que "a Polícia Militar, principalmente pelas suas unidades especializadas, pode fazer a prevenção a repressão das infrações florestais, inclusive o respectivo inquérito, salvo quando o fato ocorrer em terras da União ou tiver repercussão interestadual ou internacional, cabendo então o inquérito, e só ele, à Polícia Federal, que detém exclusividade na função", enquanto que "a Polícia Civil poderá, concorrentemente com a Polícia Militar e ressalvada a competência da Polícia Florestal, efetuar o inquérito sobre as infrações penais florestais, não lhe cabendo missões preventivas, administrativas, por falta de previsão legal, em nível constitucional e infraconstitucional".

Todos esses aspectos do Direito Administrativo e que envolvem o Poder de Polícia devem ser considerados por quem o detenha no âmbito do Direito Ambiental, pois, para considerar-se regular o seu exercício, ele há de ser "desempenhado pelo órgão competente nos limites da lei aplicável, com observância do processo legal e, tratando-se de atividade que a lei tenha como discricionária, sem abuso ou desvio de poder", conforme cuida o art. 78, parágrafo único, da Lei federal $n^{0} 5.172$, de 25 de outubro de 1966, conhecida como Código Tributário Nacional, pois, dispõe sobre o Sistema Tributário Nacional e instituiu normas gerais de direito tributário aplicáveis à União, Estados e Municípios, lembrando a propósito, que o poder administrativo que examino, o Poder de Polícia, ainda hoje é referido uma única vez na Constituição da República, ou seja, em seu art. 145, II, ao tratar dos princípios gerais Do Sistema Tributário Nacional e prever "taxas, em razão do exercício do poder de polícia".

Regular, asșim, o ato de polícia administrativa, ele goza de atributos, que são o discricionarismo, a auto-executoriedade e a coercibilidade, próprios do Poder de Polícia.

A discricionariedade é o uso da liberdade legal de valoração da atividade policiada, sendo que esse atributo diz respeito, também, à gradação das sanções administrativas aplicáveis aos infratores. Lembro, porém, que o discricionarismo de que falo, diz respeito a conveniência e oportunidade da prática do ato de polícia diante da atividade policiada, não se confundindo com arbítrio, com arbitrariedade.

O Poder de Polícia há de ser exercido dentro dos limites impostos pela lei, pela realidade e pela razoabilidade, sob pena de resvalar para a arbitrariedade a autoridade que não observe tais limites, com a consequiência jurídica decorrente do seu abuso de autoridade, por excesso ou desvio de poder.

A auto-executoriedade do ato de polícia administrativa importa em ele produzir todos os seus efeitos de imediato, isto é, ser colocado em execução desde logo, 
independente de prévia autorização do Poder Judiciário, que só poderá ser chamado a intervir a posteriori. Lembro, novamente, que o Poder de Polícia objetiva conter excessos, a atividade anti-social e, em tema do meio ambiente, preservar ou conservar a denominada massa verde (florestas, matas etc.) e a chamada massa cinza (meio urbano), dando proteção ao homem contra a degradação ambiental, razão pela qual não ser possível condicionar atos de polícia, inclusive quanto as sanções administrativas, à prévia aprovação de qualquer outro órgão de Poder estranho à Administração Pública.

No que se refere à coercibilidade, lembro que todo ato de polícia é imperativo, isto é, obrigatório ao seu destinatário, que, se resistir, ensejará, até mesmo, o emprego de força física para a remoção do obstáculo oposto ao seu cumprimento.

O ato de polícia, bem por isso, não é facultativo ao administrado, de vez que tem coercibilidade estatal para torná-lo efetivado. Essa coerção, como focalizado, dado o atributo da auto-executoriedade, independe de autorização judicial, porque é a própria Administração Pública que decide e toma as providências cabíveis para a realização do que se decidiu, impessoalmente, inclusive aplicando, dentro da discricionariedade que lhe é inerente as penalidades administrativas que a lei de regência, expressamente indique para infraçōes administrativas ao Direito Ambiental.

\section{Sanções administrativas ambientais}

A propósito da sanção de polícia ambiental, tema deste estudo, devo esclarecer que me alinho com o publicista alemão Otto Mayer, separando a pena de polícia do constrangimento de polícia, que se caracteriza no obrigar outrem a fazer ou deixar de fazer o que era de seu desejo, subordinando-o compulsoriamente, de maneira pessoal, imediata e direta, ao interesse público. Por sua vez, a pena de polícia, limitada à esfera administrativa e prevista taxativamente na legislação de regência da atividade policiada, tem sentido de castigo, ainda que por imposição pecuniária, revelando-se como intervenção punitiva do Estado sobre as atividades e as propriedades particulares dos administrados, sendo aplicadas, unilateral e imperativamente aos infratores ${ }^{16}$, por quem tenha competência legal para tanto.

Não se pode esquecer nesta oportunidade que, para o tema em exame, "sanção significa o meio coercitivo disposto pela própria lei, para que se imponha o seu mando, ou a sua ordenança. Assim, sanção e coercibilidade têm significados idênticos, tendentes ambos a assinalar as vantagens ou as penalidades decorrentes do cumprimento ou da falta de cumprimento do mando legal. Em princípio, toda norma legal traz a própria sanção, em virtude do que há sempre uma vantagem, ou uma

16 LAZZARINI, Alvaro. O Esforço no Contexto do Trânsito, "Revista de Informação Legislativa", Senado Federal, Subsecretaria de Ediçōes Técnicas, Brasília, a. 30, n. 117, jan./mar. 1993, p. 67-88; idem revista "Unidade", editada pela Associação para Pesquisas Policiais (Oficiais PM da Brigada Militar do Rio Grande do Sul), Porto Alegre, $\mathrm{n}^{\mathrm{Q}} 16$. 
pena ligada ao seu fiel cumprimento ou à sua transgressão. Por ela é que se torna efetiva a coação, asseguradora do direito, pela qual se convoca a proteção do poder público" 17.

Sanção administrativa ambiental, portanto, é uma pena administrativa prevista expressamente em lei para ser imposta pela autoridade competente quando violada a norma de regência da situação ambiental policiada.

A sanção administrativa ambiental, assim, há de estar expressamente prevista na lei de regência, aplicando-se, analogicamente, o princípio da reserva legal do Direito Penal, consubstanciado na previsão de que não há pena sem prévia cominação legal, hoje com dignidade constitucional (art. 5o , inciso XXXIX, da Constituição de 1988). Não se pode aplicar, em consequiência, sanção administrativa ambiental que não esteja catalogada na lei anterior à ocorrência do ilícito administrativo de natureza ambiental.

A sanção administrativa ambiental tem duplo objetivo, ou seja, ela tem por fim a correção do infrator, no que representa um verdadeiro castigo para que melhore a sua conduta de respeito às normas legais ambientais, como também um fim de prevenção, no sentido de servir de verdadeiro alerta a todos os outros, e ao próprio infrator, das conseqüências da infração ambiental.

Podemos classificar as sanções administrativas, que concretizam a tutela administrativa ambiental em (a) sanções pecuniárias, como as multas aplicadas em razão da não observância das normas de proteção ambiental; e (b) sanções objetivas, como as que envolvem bens e/ou serviços como apreensões, cancelamento do registro, cancelamento de matrícula de pescador profissional, interdição do barco, embargos de iniciativas particulares etc.

A sanção administrativa ambiental, sendo punição, deve ser imposta através do devido procedimento legal. Tal procedimento, de natureza administrativa, obrigará a autoridade administrativa ambiental, em linhas gerais, a assegurar ao acusado o contraditório e a ampla defesa, com os meios e recursos a ela inerentes (art. $5^{\circ}$, inciso LV, da Constituição da República e, no Estado de São Paulo e seus Municípios, art. $4^{\mathfrak{0}}$, combinado com o art. 144 da sua Constituição).

A acusação será formulada formalmente através de Auto de Infração Ambiental, que será motivado com a narração circunstanciada da infração verificada e seu enquadramento na legislação ambiental, de tudo notificado o acusado para que possa produzir, no prazo legal, sua ampla defesa, contraditando a acusação - esta sendo ato administrativo tem o atributo da presunção de veracidade e de legitimidade (princípio da veracidade e da legitimidade dos atos administrativos), só podendo ser infirmada por prova cabal em sentido contrário a ser produzida pelo acusado — , seguindo-se a fase probatória se pertinentemente requerida, sob pena de cerceamento de defesa, e, finalmente, a decisão final que a autoridade ambiental competente entenda de dar à hipótese examinada no procedimento administrativo ambiental, sempre com o recurso previsto em lei e que o caso comporte.

17 DE PLÁCIDO E SILVA. Vocabulário Jurídico, v. VI, $1^{\mathbf{a}}$ ed., 1963, Editora Forense, Rio de Janeiro, p. 1.402-3, verbete "Sanção". 
Se aplicada sanção administrativa ambiental, ela, necessariamente, deve vir motivada, lembrando-se que, no Estado de São Paulo, a sua Constituição obriga à motivação de todos os atos da Administração Pública não só da estadual (arts. $4^{\mathfrak{Q}} \mathrm{e}$ 111), como também da de seus municípios, estes por força de seu art. 144 .

Deve, também ser salientado que, dado a autonomia das instâncias administrativa, civil e penal, não ocorrerá o bis in idem na hipótese de, apesar da ocorrência de apenação civil e criminal, sempre mais demoradas a efetivar-se, ocorrer, também a sanção administrativa ambiental, sempre mais célere. $\mathrm{O}$ bis in idem, como sabido, é a repetição (bis) da punição sobre a mesma conduta faltosa (in idem) o que é vedado e torna nulo o ato sancionador repetitivo.

Em razão da aludida autonomia das instâncias, a autoridade ambiental competente não deverá aguarda a solução criminal ou civil, devendo, desde logo, aplicar a sanção administrativa adequada a todo infrator nas normas ambientais, observando-se que, também, dado o atributo da auto-executoriedade do Poder de Polícia, que está exercendo, a sanção independe de autorização do Poder Judiciário para efetivar-se. $O$ Poder Judiciário só deve fazer controle posterior ao ato administrativo punitivo e, mesmo assim, se provocado pelo destinatário do ato.

Podemos, assim, catalogar as sanções administrativas ambientais previstas no nosso ordenamento jurídico ambiental.

Sanções administrativas ambientais são encontradas no Código Florestal (Lei Federal $\mathrm{n}^{2} 4.771$, de 15 de setembro de 1965 , com as alterações decorrentes das Leis Federais nºs. 7.803 , de 18 de julho de 1989 , e 7.875 , de 13 de novembro de 1989 . O seu artigo 20, parágrafo único, por exemplo prevê que as empresas industriais serão apenadas com multa equivalente a $10 \%$ (dez por cento) do valor comercial da matéria-prima florestal nativa consumida além da produção da qual participe, na hipótese da empresa não cumprir o comando do seu caput, ou seja, a manter dentro de um raio em que a exploração e o transporte da matéria-prima florestal sejam julgados econômicos, um serviço organizado, que assegure o plantio de novas áreas, em terras próprias ou pertencentes a terceiros, cuja produção, sob a exploração racional, seja equivalente ao consumido para o seu estabelecimento.

A apreensão dos produtos e dos instrumentos utilizados na prática de infrações penais, determinadas no artigo 35 do Código Florestal, por ser da responsabilidade das autoridades administrativas a que alude o seu artigo 33, embora destinadas à prova criminal, não deixa de ter, também, conotação de sanção administrativa.

A Lei de Proteção à Fauna, Lei Federal $n^{0}$ 5.197, de 3 de janeiro de 1967, em linhas gerais não apresenta sanções administrativas, salvo a do cancelamento do registro de que trata o seu artigo 16, instituído para as pessoas físicas ou jurídicas que negociem com animais silvestres e seus produtos, incidindo a sanção, de ordem administrativa, na hipótese da pessoa registrada não apresentar a declaração de estoques e valores, sempre que exigida pela autoridade competente (artigo 17, caput e parágrafo único). A apreensão dos produtos de caça elou pesca, bem como dos instrumentos utilizados em infrações penais, inclusive a sua destinação, em se tratando de produtos perecíveis, com doação a instituições científicas, penais, hospitais e/ou casas de caridade mais próximas, sendo da responsabilidade de autorida- 
des administrativas competentes, novamente comparece na legislação de regência como nítida sanção administrativa de polícia ambiental.

O Código de Pesca, Decreto-lei Federal no 221, de 28 de fevereiro de 1967, é o que melhor cuida das sanções administrativas. Ao tratar das embarcações pesqueiras, no seu artigo $6^{\circ}$, caput e parágrafo único, dispõe que toda embarcação, nacional ou estrangeira, que se dedique à pesca comercial, além do cumprimento das exigências das autoridades marítimas, deverá estar inscrita e autorizada pelo órgão público federal competente, sob pena administrativa de interdição do barco até a satisfação das exigências impostas pelas autoridades competentes.

O seu artigo $9^{\circ}$, caput e parágrafo único, exige que as embarcações estrangeiras, para realizar atividades pesqueiras nas águas brasileiras de que trata o artigo $4^{\circ}$, deverão estar autorizadas por ato administrativo do Ministro de Estado dos Negócios da Agricultura, podendo o Poder Público, além de responsabilizar criminalmente o comandante, determinar administrativamente a interdição da embarcação, seu equipamento e carga.

Interdição do funcionamento do estabelecimento respectivo, sem prejuízo da multa respectiva, igualmente, são sanções administrativas previstas no artigo 19, parágrafo único, do Código de Pesca. A hipótese é de infração ao determinado no caput do referido artigo, que exige que se obtenha prévia autorização do órgão público federal competente para exercer suas atividades no território nacional ou nas águas abrangidas pelo referido Código de Pesca, devendo estar devidamente inscrita e cumprir as obrigações de informações e demais exigências que forem estabelecidas.

O seu artigo 25 autoriza aplicar sançōes administrativas ao armador que deixar de oferecer seguro contra acidentes de trabalho aos tripulantes das embarcações pesqueiras, bem como deixar de filiá-los a instituições de Previdência Social.

Cancelamento de matrícula de pescador profissional, como sanção administrativa, é encontrada no artigo 26, parágrafo único, quando for comprovado que o pescador não faça da pesca sua profissão habitual ou quando infringir as disposições do referido Código de Pesca e seus regulamentos, no exercício da pesca.

O Código de Pesca, ao contrário dos anteriores examinados, tem a peculiaridade de dedicar todo um Capítulo, o Capítulo VII, às multas, como sanção administrativa, prevendo, no seu artigo 65, que todas as informações previstas no Código, sem prejuízo da ação penal correspondente, sujeita os infratores ao pagamento de multa na mesma base das estabelecidas no Capítulo anterior, o Capítulo VI, artigos 55 a 64.

Essas multas serão impostas por despacho da autoridade competente em processo administrativo (artigo 66), cujo rito está previsto nos artigos 67 a 69, havendo, também, a previsão da inscrição da multa não paga nos prazos para cobrança em execução fiscal (artigo 70), bem como a destinação do arrecadado como "Recurso da Pesca" (artigo 72).

A Lei Federal n 7.679 , de 23 de novembro de 1988, que dispõe sobre proibição da pesca de espécies em período de reprodução e dá outras providências, nos artigos $4^{0}$ e $5^{0}$, igualmente, prevê sanção administrativa de multa aos pescadores profissionais e aos pescadores amadores, bem como às empresas que exploram a pesca quando violarem suas normas proibitivas. 
A criação das Estações Ecológicas e de Áreas de Proteção Ambiental estão disciplinadas pela Lei Federal $n^{0} 6.902$, de 27 de abril de 1981. As Estações Ecológicas serão criadas pela União, Estados e Municípios em terras de seus domínios (artigo $2^{2}$ ). O seu artigo $7^{\mathfrak{Q}}$ elenca as proibições a serem observadas nas Estações Ecológicas, sujeitando o infrator à apreensão do material proibido e ao pagamento da indenização pelos danos causados (artigo $7^{0}, \S 3^{\mathfrak{a}}$ ), penalidades essas a serem aplicadas pela Administração da Estação Ecológica (artigo $7^{\mathfrak{Q}}$, $4^{\mathbf{0}}$ ).

A Lei Federal $n^{0} 6.902$, de 1981 , no seu artigo $9^{9}$, também, precisa que, dentro dos princípios constitucionais que regem o exercício do direito de propriedade, o Poder Executivo deve estabelecer normas limitadoras ou proibitivas relativas a esse direito, competindo ao Instituto Brasileiro do Meio Ambiente e dos Recursos Naturais Renováveis - IBAMA, ou órgão equivalente no âmbito estadual, em conjunto ou isoladamente, ou mediante convênio com outras entidades, fiscalizar e supervisionar as Áreas de Proteção Ambiental (artigo $9^{\mathbf{0}}, \S 1^{\mathbf{Q}}$ ).

No caso de violação às normas de que cuida o referido artigo $9^{\circ}$, dispõe o seu $\S 2^{0}$ que os infratores estão sujeitos às sanções de embargo das iniciativas irregulares, à medida cautelar de apreensão do material e das máquinas utilizadas nessas atividades, à obrigação de reposição e reconstituição, tanto quanto possivel, da situação anterior e à imposição de multas.

Todas essas penalidades administrativas serão aplicadas por iniciativa do Instituto Brasileiro dos Recursos Naturais Renováveis - IBAMA, ou do órgão estadual correspondente e constituirão, respectivamente, receita da União ou do Estado, quando se tratar de multa, certo que, quanto a esta última sanção administrativa, a de multa, aplicam-se as normas da legislação tributária e do processo administrativo fiscal que disciplinam a imposição e a cobrança das penalidades fiscais (artigo $9^{\circ}$, $\S \S 3^{0}$ e $4^{9}$ ).

Dispondo sobre a Política Nacional do Meio Ambiente, seus fins e mecanismos de formulação, além de dar outras providências, a Lei Federal $\mathrm{n}^{0} 6.938$, de 31 de agosto de 1981, no seu artigo 14, é expressa em dizer que, sem prejuízo das penalidades definidas pela legislação federal, estadual e municipal, o não cumprimento das medidas necessárias à preservação ou correção dos inconvenientes $e$ danos causados pela degradação da qualidade ambiental sujeitará os transgressores às sanções administrativas previstas em seus incisos, isto é, à de multa simples ou diária (I), à perda ou restrição de incentivos e benefícios ficais (II), à perda ou suspensão de participação em linhas de financiamento (III) e à suspensão de sua atividade (IV).

O Regulamento da Lei Federal $n^{0} 6.902$, de 27 de abril de 1981, que cuida da criação de Estações Ecológicas, Áreas de Proteção Ambiental e dá outras providências, e da Lei Federal $n^{2} 6.938$, de 31 de agosto de 1981, que dispõe sobre a Política Nacional de Meio Ambiente e dá outras providências, está consubstanciado no Decreto Federal $\mathrm{n}^{2} 99.274$, de 6 de junho de 1990, em cujo Título III, encontram-se relacionadas as infrações ambientais e os valores das multas respectivas, definindo o seu artigo 33 que "Constitui infração, para os efeitos deste Decreto, toda ação ou omissão que importe na inobservância de preceitos nele estabelecidos ou na deso- 
bediência às determinações de caráter normativo dos órgãos ou das autoridades administrativas competentes".

Os seguintes artigos 34 a 39 cuidam especificamente da imposição das penas de multa, merecendo ser salientado que, quando as informações forem causadas por menores ou incapazes, responderá pela multa quem for juridicamente responsável pelos mesmos (artigo 40) e, em qualquer caso, a imposição de penalidades pecuniárias, por infração à legislação ambiental pelos Estados, pelo Distrito Federal e pelos Municípios, excluirá a exigência de multas federais, na mesma hipótese de incidência (artigo 41), com o que se proíbe o denominado bis in idem.

Em qualquer das hipóteses de aplicação da pena de multa, ele poderá ter a sua exigibilidade suspensa quando o infrator, por termo de compromisso aprovado pela autoridade ambiental que aplicou a penalidade, se obrigar à adoção de medidas específicas para cessar e corrigir a degradação ambiental, certo que, cumpridas as obrigações assumidas pelo infrator, a multa será reduzida em até noventa por cento (artigo 42, caput e parágrafo único).

\section{Conclusão}

Sanção administrativa ambiental é pena administrativa prevista em lei anterior que trate do meio ambiente e a ser imposta por autoridade pública competente ao violador da norma ambiental preexistente.

Na sanção administrativa ambiental se concretiza o Poder de Polícia Ambiental que, sem ela, ficaria inane, devendo ser aplicada em regular procedimento administrativo ambiental, assegurando-se ao acusado o contraditório e a ampla defesa, com os meios e recursos a ela inerentes, tudo independentemente de solução de processo criminal ou civil que a violação da norma ambiental possa ensejar. 


\section{A Evolução da Ordem Pública no Direito Internacional Privado}

Jacob Dolinger

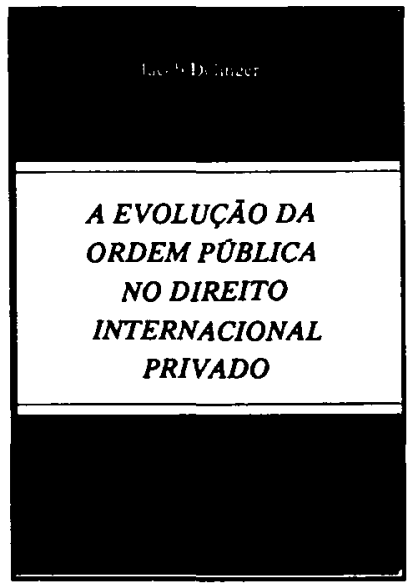

Esta obra versa o princípio da ordem pública no direito internacional privado, que representa a mais importante "válvula de escape" de que se utilizam juízes e tribunais do mundo todo, para deixar de aplicar a lei estrangeira indicada pelas regras de conexão, sempre que sentirem que a norma estrangeira não é consentânea com os princípios fundamentais do direito do foro.

$\begin{array}{lll}\text { Ref. 0071 } & \text { Distribuição } & \text { Brochura } \\ 282 \text { págs. } & \text { Form. 16x23 } & 1979\end{array}$

\section{A Face Legal do Dinheiro}

Letácio Jansen

O autor, considerado a maior autoridade no Brasil em Direito Monetário, fez uma análise doutrinária da Obrigação Monetária e ainda utilizou as categorias por ele desenvolvidas para estudar as questōes monetárias brasileiras, especialmente os Planos Cruzados, Bresser, Verão e Collor. Esta obra contém minuciosos índices que foram elaborados para permitir a localização imediata do tema pesquisado e constitui, enfim, o mais amplo e atualizado estudo, em língua portuguesa, publicado na América Latina, sobre o dinheiro, em sua expressão legal.

Ref. 0027

Brochura

Form. 14x21

324 págs.

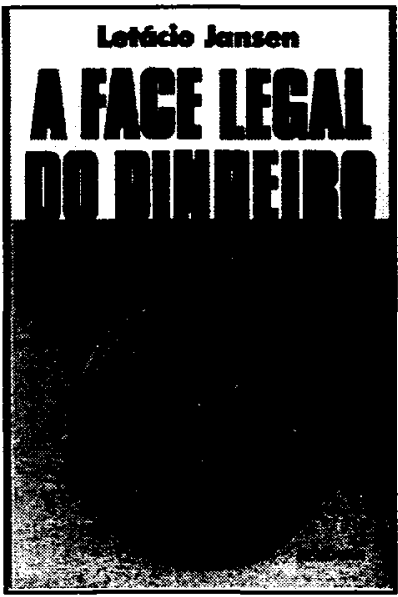

